\title{
Review
}

\section{The paradox of liberation: Secular revolutions and religious counterrevolutions}

\author{
Michael Walzer \\ Yale University Press, New Haven, 2015, xiv+172pp., \\ ISBN: 978-0-300-18780-9
}

Contemporary Political Theory (2017) 16, 434-438. doi:10.1057/s41296-016-0074-y; advance online publication 28 September 2016

Secular political settlements around the world face a growing crisis of legitimacy. The global resurgence of religion over recent decades has challenged fundamental assumptions regarding "the line between, and the content of, the religious and the secular" (Hurd, 2007, pp. 661-662). Against the liberal conception of religion as a private and depoliticized matter of individual conscience, movements such as the Justice and Development Party in Turkey and the Bharatiya Janata Party in India draw on religious traditions as sources for political action and national identity. It increasingly seems, as Jürgen Habermas puts it, we are witnessing the dawn of a new political formation: the postsecular society.

This anxious moment has renewed debate regarding the relationship between politics and religion. Surveying the state of this conversation in Dissent, Michael Walzer (2015) observed that it reveals the left's "difficulty recognizing the power of religion." If the religious revival is a "testing moment" for the political left, "some of us are trying to meet the test; many of us are actively failing it." Meeting this challenge, Walzer claims, requires overcoming the notion that public religions are epiphenomenal expressions of deeper grievances with the global capitalist and neo-liberal order - or that they can be easily enlisted as allies against these familiar enemies of the left. Walzer insists that the left "should clearly name the zealots [as] our enemies and commit ourselves to an intellectual campaign against them - that is, a campaign in defense of liberty, democracy, equality, and pluralism."

Walzer refines this point in The paradox of liberation. Based on the Henry L. Stimson Lectures he gave at Yale University in 2013, Walzer's book analyzes the trajectory of several secular national liberation movements, which each achieved early success only to eventually engender "religious movements that challenged the achievement roughly a quarter century later" (p. ix). The immediate question of why these liberation movements produced this counter-revolutionary response

(c) 2016 Macmillan Publishers Ltd. 1470-8914 Contemporary Political Theory Vol. 16, 3, 434-438 www.palgrave.com/journals 
allows Walzer to approach a "deeper" mystery: "What happened to the secular democratic left" (p. xiv)? And how can the lessons of these efforts facilitate a more robust and sustainable form of left politics?

The book tackles these questions by examining three nationalist movements from the mid-twentieth century - the National Liberation Front (FLN) in 1962 Algeria, the Zionist creation of Israel in 1948, and the Indian National Congress in 1947 - that were all eventually challenged by religious movements. These secular movements, Walzer explains, all stumble because of what he calls the "paradox of liberation." The mechanics of this paradox are straightforward. Secular liberators undertake a project of removing their people from oppression, either by removing an occupying power (as in India and Algeria) or by consolidating an exiled population into a new polity (as with Israel). This project of liberation entails not only displacing the oppressors but also weeding out "the internal effects of external oppression" (p. 1), that is, the cultural formations, collective dispositions, and social habits cultivated under conditions of domination that can undermine self-governance. As Walzer puts it: "The old ways must be repudiated and overcome - totally. But the old ways are cherished by many of the men and women whose ways they are. That is the paradox of liberation" (p. 19).

The definite article in this formulation is striking. Walzer narrows his meaning by specifying that he is referring to "the paradox of national liberation" (p. 1). The paradox refers to a specific mode of liberation, where the strategy of completely repudiating tradition sows the seeds for a counter-revolutionary movement that repurposes those traditional materials against left principles. Arguably, the more radical paradox associated with national liberation is not one of a particular strategy but rather how framing liberation in terms of the nation-state invites a series of internal tensions and constraints. Consider Saba Mahmood's examination of the politics of minorities claiming religious freedom under secular liberalism. She writes, "On the one hand, a minority is supposed to be an equal partner with the majority in the building of the nation; on the other hand, its difference (religious, racial, ethnic) poses an incipient threat to the identity of the nation that is grounded in the religious, linguistic, and cultural norms of the majority" (2015, p. 32). Minorities therefore are caught in a double bind: making a claim for the political goods Walzer associates with the left (equality, liberty, pluralism) requires them to highlight their difference from the identity of the nation, which can exacerbate the original perception of the group as outside and potentially subversive of that national identity. In this way, the "structural challenges" that confront minority claims to equality illuminate how the very concept of the nation can frustrate the aims of liberation (2015, pp. 66-67).

Walzer entertains critiques of this nature in his chapter "The Paradox Denied." Marxists, for instance, might fault the liberation movements for being insufficiently secular since they remain centered on the nation rather than on an international 
campaign (p. 83). Walzer deflects this line of critique, explaining that a Marxist movement would have repeated the dynamic of the national movements, where abstract principles attempt to displace "archaic emotions" (p. 86). Furthermore, a cosmopolitan project may emerge eventually, but historically this project "has never come [before national liberation], and efforts to make it come first do not bring anything like liberation" (p. 86). Still, at the close of this chapter, Walzer explains, "The proving ground for every national liberation movement is the nation or the ethnic or religious group that comes next: the Jews are tested by the Palestinians, the Algerian Arabs by the Berbers, and the Indians by the Muslims in their largely Hindu nation-state. Right now, none of the three nations is scoring very high" (p. 102). Curiously, Walzer never considers whether the concept of the nation might be part of why these liberation movements fall short. Thus, we might wonder if the framework of the nation-state may be both historically necessary (as Walzer claims) but also structurally limiting (as Mahmood suggests) when it comes to liberation - and that this dynamic constitutes a more fundamental and troubling paradox of national liberation.

Drawing attention to these complications does not deny the existence of the specific dilemma Walzer points to or imply that his puzzle "isn't the right question" (p. 67). It merely suggests that Walzer's questions must be examined in conjunction with other contradictions of the nation-state as a model for conceptualizing left politics. The existence of other paradoxes does not diminish the value of Walzer's central insight that anti-religious strategies of liberation impoverish political culture in a way that prevents the reproduction of a stable collective identity over time. It is impossible not to note the convergence of Walzer's analysis here with Edmund Burke's reflections on the French Revolution. Although coming from different political sensibilities - with Walzer hoping to restore the prospects of left politics and Burke forging the foundations for modern conservatism - both thinkers portray the modern revolutionary project as problematically emaciated and absolutist. According to both accounts, the revolutionary left unwisely jettisons socio-political resources within national traditions, particularly religious traditions. Yet, whereas Burke's political sympathies lead him to worry that secular revolutions will inevitably resort to violence in the absence of the social glue of tradition, Walzer's analysis is more concerned with actors who seize upon religious traditions to fill the cultural vacuum left by secularists.

The shared flaw of Burke's revolutionaries and Walzer's liberators is a misplaced faith in the power of reason. In Walzer's examples, this faith takes the form of a belief in the secularization thesis, which held that the privatization and eventual withering away of religious faith were sociological inevitabilities. Jawaharial Nehru, the major figure in the creation of the Indian nation-state, 
exemplifies this expectation that religion would "vanish at the touch of reality" (quoted in Walzer, p. 111). Thus, the liberators' "secular fear" of the power of religious traditions' oppressive potential was compounded by a "secular blindness" that led them to believe that this power would necessarily decline and disappear (p. 111). Walzer is upfront about his own secularist perspective, characterizing himself as a "radical critic of the religious tradition" (p. 126) who lives with "a generalized fear of every form of religious militancy" (2015). Walzer argues, however, that the left must appreciate the enduring power of religion, and must recognize its true opponent, which is not religion but rather militant religious actors ("zealots") who challenge principles of equality, democracy, liberty, and pluralism.

Yet if liberators should negotiate rather than negate religious traditions, what does this engagement mean in practice? What are the conditions and processes by which it can take place? The few details that Walzer provides are suggestive, yet the discussion toggles between dissonant visions of how the left should proceed. At certain moments Walzer's sketch is promisingly mutual and open, such as when he invokes an alternative form of Zionism where secular forces and traditional Judaism are "brought into a dialectical relation, in which each influences the other and the two are transformed in some interactive way" (p. 66). Elsewhere this relation comes across as one-sided. For example, Walzer states that selective reclamation of religious traditions means that "Western ideas about liberty and equality can be naturalized in India" (p. 117). Rather than a dialectical dynamic of mutual re-construction, negotiation becomes a matter of instrumentalizing traditions to legitimate pre-existing "Western ideas" of what these concepts mean. Engagement in this valence risks repeating the problem in a different register, with the left's principled disdain for religion repackaged as cynical manipulation and exploitation. To escape this paradox, the left must engage religious communities in a symmetrical, vulnerable, and authentic fashion. Such a symmetrical engagement gives up on imposing a predetermined model of liberation in favor of a model of politics that is "liberating in a new way: now the end is open, radically uncertain or, better, there are many different engagements and many different, always temporary, outcomes" (p. 133).

This open-endedness is of apiece with Walzer's project as a whole. Liberation, Walzer stresses, "is an ongoing project" (p. 146). It should not be thought of as a singular event of radical rupture. Rather (in another echo of Burke) liberation is more productively conceived of as an iterative process of incremental developments over time. So too is the effort to rethink the terms of left politics, and in that ongoing project, Walzer has provided a valuable contribution to the left's effort to grapple with religion in this postsecular moment. 


\section{References}

Hurd, E.S. (2007) Theorizing religious resurgence. International Politics 44: 647-665.

Mahmood, S. (2015) Religious difference in a secular age: A minority report. Princeton: Princeton University Press.

Walzer, M. (2015) Islamism and the left. Dissent. https://www.dissentmagazine.org/article/islamismand-the-left.

Brendan J. Wright

Princeton University, Princeton, NJ 08544, USA

bjwright@princeton.edu 